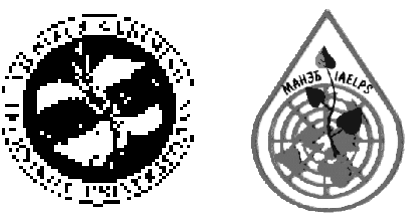

\title{
PECULIARITIES OF HARD COSMIC RADIATION VARIATIONS NEAR THE GROUND SURFACE IN ACCORDANCE WITH GEOMAGNETIC ACTIVITY CHANGES
}

\author{
Dmitrijus Styra $^{1}$, Jonas Gaspariūnas ${ }^{2}$, Ana Usovaité $\dot{e}^{3}$ \\ 1, ${ }^{3}$ Dept of Physics, Vilnius Gediminas Technical University, Saulètekio al. 11, \\ LT-10223Vilnius-40, Lithuania.E-mail: styra@fm.vtu.lt \\ ${ }^{2}$ Dept of Theoretical Mechanics, Vilnius Gediminas Technical University, Saulètekio al. 11, \\ LT-10223 Vilnius-40, Lithuania
}

Received 30 Apr 2004; accepted 27 May 2004

\begin{abstract}
The mechanism of primary cosmic particle transformation into secondary radiation near the ground surface is analysed. It is known that the main part of secondary cosmic radiation consists of muons. They are formed after nuclear reactions between primary protons and the nuclei of atmospheric gases. Maximum muon concentrations are formed at an altitude of $15 \mathrm{~km}$ from the ground surface. Because of a short existence time of muons $(2 \mu \mathrm{s})$, the amount of these particles near the ground surface depends on variations in the altitude of the above-mentioned atmospheric layer. Therefore, an unstable flux of muons is registered near the ground surface. Their variations are connected with the Sun's radiation instability, geomagnetic field variations, meteorological process changes, etc.

Measurements of the hard cosmic radiation component only near the ground surface are carried out. To this purpose protection of the detector of gamma-spectrometer was improved. Small gaps between lead plates were made to abolish the shower phenomenon caused by cosmic radiation and the effect of weak-energy particles and as a result to improve the measurement accuracy. It is defined that lead protection of the thickness of $9 \mathrm{~cm}$ of the detector fully absorbs muons with $1,6 \mathrm{MeV}$ energy. It is registered that the gamma-quanta of $1,6 \mathrm{MeV}$ energy of radionuclide ${ }^{232} \mathrm{Th}$ lose $70 \%$ of the initial energy only in the same lead protection.

In 2001-2002 a study was made of the course of the hard cosmic ray flux (HCRF) near the ground surface in four energy intervals: $1-0,3-1,2 \mathrm{MeV}, 2-1,2-1,6 \mathrm{MeV}, 3-1,6-4 \mathrm{MeV}, 4-4 \mathrm{MeV}$ and more. Various course of the HCRF in the mentioned intervals is obtained.

Simultaneous coincidence of the HCRF course in all the energy intervals was observed only from 6,5 to $9,6 \%$ in $2001-$ 2002.

The obtained results indirectly indicate an unstable altitude of the atmospheric layer where maximum concentration of muons is formed. This instability is connected with the meteorological and geomagnetic field changes affecting the human health.
\end{abstract}

Keywords: cosmic radiation, muons, gamma-quanta, energy intervals, lead protection.

\section{Introduction}

Nowadays an intensive increase of industry, power engineering, agriculture, etc, influence the environment and the action on the human organism. The after-effects of the above stated sources occur in the air and drinking water quality change, contamination of the biosphere by chemical wastes, extra thermal effects, etc. Influence of the above mentioned effects on the human health and the reaction of the external and internal action becomes different. Moreover, the anthropogeneous factors of the action on the human organism, natural phenomena become also effective in accordance with natural catastrophes - whirlwind, hurricanes, earthquakes, etc. Influence on the human organism is also possible from weak and frequent actions, for instance, by meteorological situation changes, variation of the Sun's activity, geomagnetic field change, etc. Naturally, the human organism in a certain degree adapts to many negative effects. However, the above mentioned actions in a larger or less degree cause organism disorders.

In the present paper analysis of external action on the human organism is limited only to geomagnetic effects which disorder the cardiovascular system [1, 2].

It is found out that the investigation of geomagnetic activity is not necessary because it can be replaced 
by an indirect indicator - the hard cosmic ray flux (HCRF) [3]. It is determined that the variations of the absolute values of the HCRF limited by optimum criteria can predict the tendency of cardiovascular disease (CVD) change in some days [4].

In this case a new important scientific problem arises concerning cosmic particle energy variations predicting the human health change.

Near the ground surface major part of the HCRF consists of muons with different energy. The registration of these particles is carried out by a gamma-spectrometer having a scintillation crystal $\mathrm{NaI}(\mathrm{Tl})$ [4]. The change of cosmic particle number per time unit indirectly predicts the influence of geomagnetic field variations on people and its after-effects $[1,2,4]$.

The aim of the investigation has two aspects. The first aspect forms the basis of the technical part of the experiment. The second one is connected with the investigation of secondary cosmic radiation and mechanism of interaction with the scintillation crystal $\mathrm{NaI}(\mathrm{Tl})$, muons spectrum form, which predicts the variations of geomagnetic field effect on people.

\section{Object of investigation}

Cosmic particles near the ground surface are different from those of Galaxy. 90 per cent of primary cosmic particles consist of protons, therefore, they interact with the nuclei of atmospheric gases. The flux of primary cosmic particles is isotropic. The majority of the nuclear reaction of protons with atmospheric gases takes place at an altitude of $25 \mathrm{~km}$, where the intensity of cosmic radiation is maximum.

As a rule, the energy of primary proton is in the range from $100 \mathrm{MeV}$ to $1,6 \mathrm{GeV}$ [5-8].

It means that before reaching the ground surface it has to make about 15 collisions with the nuclei of atmospheric gases, i e it must have 15 free paths, therefore, the probability to reach the ground surface is negligible.

Interacting with atmospheric gases, protons form new particles $\pi$-mesons with the maximum concentration at an altitude of $15 \mathrm{~km}$ [9]. The life of $\pi$-mesons is $26 \mathrm{~ns}$ and during this period of time it can move a distance of $125 \mathrm{~m}$ in the atmosphere. There are neutral $\pi$ mesons or they have positive or negative charge. Their decay schemes are as follows:

$$
\begin{aligned}
& \pi^{0}=2 \gamma, \\
& \pi^{+}=\mu^{+}+v_{\mu}, \\
& \pi^{-}=\mu^{-}+\bar{v}_{\mu},
\end{aligned}
$$

where $\gamma$ - gamma-quantum, $\mu^{+}$and $\mu^{-}-$positive and negative $\pi$-mesons, accordingly, $v_{\mu}$ and $\bar{v}_{\mu}$ - muon's neutrino and antineutrino.

The mass of muons exceeds approximately 200 times that of an electron. The life-time of muons is about $2 \mu \mathrm{s}$.
Maximum flux of muons is registered at the same altitude of $15 \mathrm{~km}$ coinciding with $\pi$-mesons maximum concentration. The energy of muons is in the range of $10 \mathrm{MeV}-10 \mathrm{GeV}$, however, the majority of these particles have energy of $100 \mathrm{MeV}$. During a short lifetime they lose about $2 \mathrm{GeV}$ of energy because of the ionization process in the atmosphere. It means that they never reach the ground surface from an altitude of 15 $\mathrm{km}$. Therefore, muons reach the ground surface from less altitudes of about some kilometres from the ground surface. Moving towards the ground surface they pass energy to atmospheric gases. The quantity of lost energy of these particles depends on primary energy, the altitude of formations, geographical location, atmospheric pressure and other meteorological processes, the geomagnetic field direction, etc.

After the life-time of $2 \mu$ s the process of muon decay is as follows:

$$
\begin{aligned}
& \mu^{-}=e^{-}+v_{\mu}+\bar{v}_{e}, \\
& \mu^{+}=e^{+}+\bar{v}_{\mu}+v_{e},
\end{aligned}
$$

where $e^{-}-$electron, $e^{+}-$positron, $v_{\mu}, \bar{v}_{\mu}-$ muon's neutrino and antineutrino, $v_{e}$ and $\bar{v}_{e}$ - electron's neutrino and antineutrino, accordingly.

Thus, the formed particles (secondary cosmic radiation) are divided into three groups according to their energy.

The first group is a "soft" component - electrons and positrons of $0,51 \mathrm{MeV}$ energy and gamma-quanta. The second group consists of muons with an average energy of $4 \mathrm{GeV}$ - the so-called "hard" component. Hence, the majority of these particles have energy of $100 \mathrm{MeV}$. Muons near the ground surface have a part of $70 \%$ of the hard component.

The third group consists of protons and neutrons of a high energy (over $1 \mathrm{GeV}$ ) moving towards the ground surface from altitudes of some kilometres.

It is known that the "soft" component of secondary cosmic radiation is absorbed by the lead of $10 \mathrm{~cm}$ in thickness.

\section{Measurement installation}

A gamma-spectrometer with a scintillation detector was used to measure the HCRF (Fig 1). The detector has a scintillation crystal $\mathrm{NaI}(\mathrm{Tl})$ which forms the light flashes of moving muons and gamma-quanta. They are intensified by a photomultifier and penetrated into an impulse analyser. The last one distributes the intensified light flashes by energy which is registered by a computer.

The detector is placed into a lead protection to be saved from penetration of the mild component of secondary cosmic radiation. The lead protection was improved and constructed in the form of a lead box (Fig 2). Lead plates of $3-5 \mathrm{~cm}$ in thickness were placed at a certain distance from one another to stop the develop- 


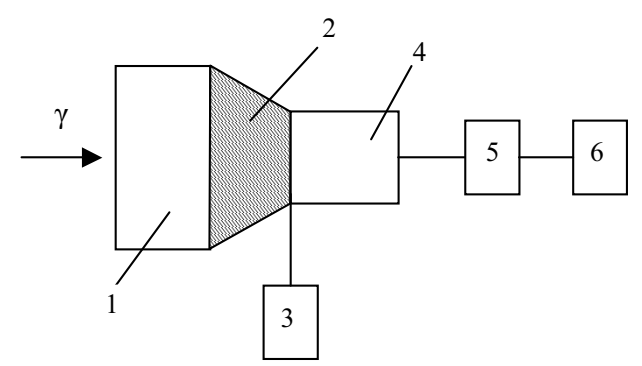

Fig 1. Scheme of measuring installation: 1 - crystal $\mathrm{NaI}(\mathrm{Tl}), 2$ - photomultiplier, 3 - high-stress generator, 4 - analyser of impulses, 5 - amplifier, 6 - computer

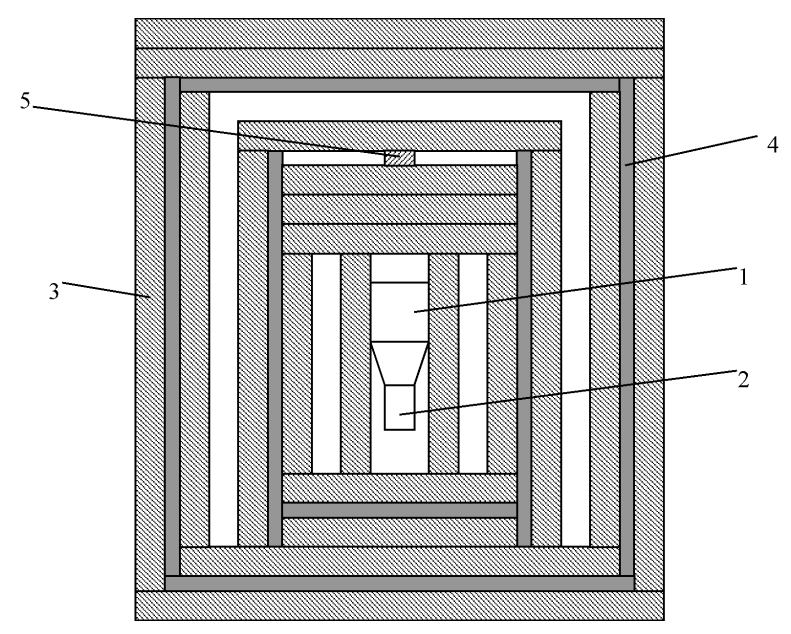

Fig 2. Lead protection with a detector inside: 1 - crystal $\mathrm{NaI}(\mathrm{Tl}), 2$ - photomultiplier, 3 - lead screens, 4 - metallic constructions, 5 - radioactive source

ment of chain reactions formed by cosmic radiation in the lead.

The total thickness of the plates in the construction is $12 \mathrm{~cm}$ which absorbs the mild component of cosmic radiation. The lead protection is covered with iron plates to save the detector from the radon decay products moving with the air flow.

\section{Physical principles of cosmic particle registration}

An example of the HCRF spectrum is illustrated in Fig 3. This spectrum is formed by "hard" particles penetrating through a lead protection of $9 \mathrm{~cm}$ in thickness into a detector. It means that the spectrum is formed by the total interaction of the mentioned particles with the crystal of the detector and Compton's scattering effect. Here the peak of ${ }^{40} \mathrm{~K}$ is observed because of the contamination of the crystal by this radionuclide.

After the interaction of muons and $\gamma$-quanta with the nodes of the crystal's grid, the scattering effect has place, i. e. the particles loose energies and change the direction of their motion (Fig 4).

According to the quantum theory, interaction be-

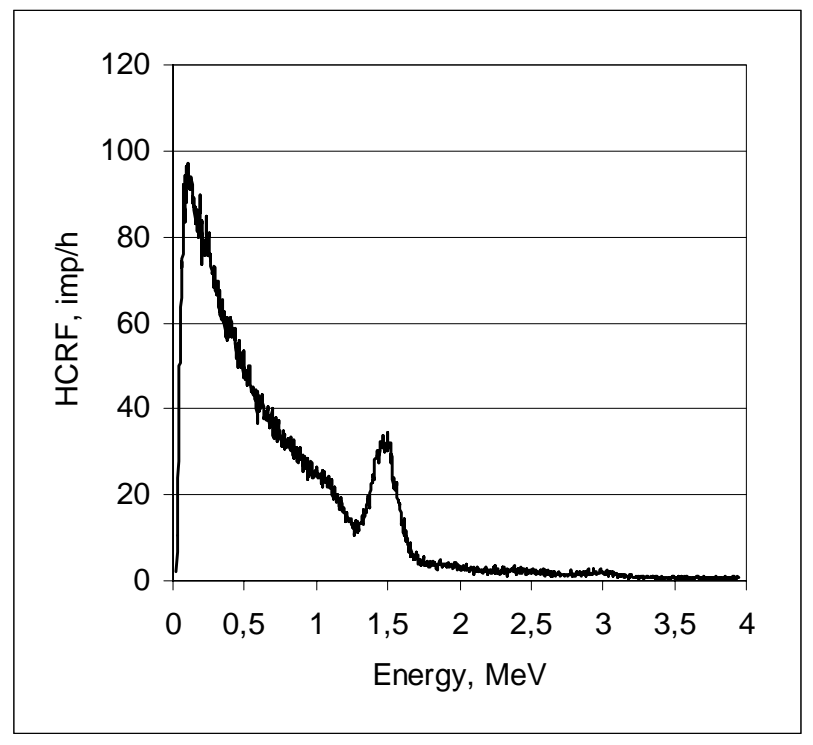

Fig 3. Distribution of impulse number per hour by the channels of an analyser with a lead protection of $9 \mathrm{~cm}$ in thickness. The peak is formed by ${ }^{40} \mathrm{~K}$ of crystal $\mathrm{NaI}(\mathrm{Tl})$

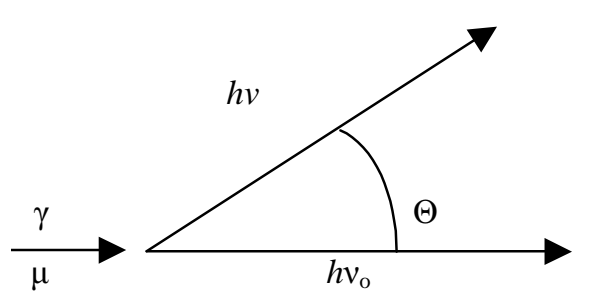

Fig 4. Compton's scattering of cosmic particles in the detector of a gamma-spectrometer

tween $\gamma$-quantum and an electron is analysed similarly to interaction between elastic balls. Thus, after interaction with an electron a gamma-quantum of $h v_{0}$ energy changes the direction of its motion losing the energy and continues moving at an angle $\Theta$ with energy of $h v$. Here $v_{0}$ - initial quantum frequency, $v$ - quantum frequency after the collision, $h$ - Plank's constant.

In accordance with the quantum-mechanical calculation [10],

$$
h v=\frac{h v_{0}}{1+\frac{h v_{0}}{m_{0} c^{2}}(1-\cos \Theta)},
$$

where $m_{0}-$ mass of an immovable electron, $c$ - light velocity. This formula is changed by dividing the numerator and denominator by $m_{0} c^{2} / h v_{0}$ and expressing $m_{0} c^{2}$ by $\mathrm{MeV}(0,51 \mathrm{MeV})$ :

$$
h v=\frac{0,51}{1+\frac{0,51}{h v_{0}}-\cos \Theta}
$$

The calculation results according to this formula 


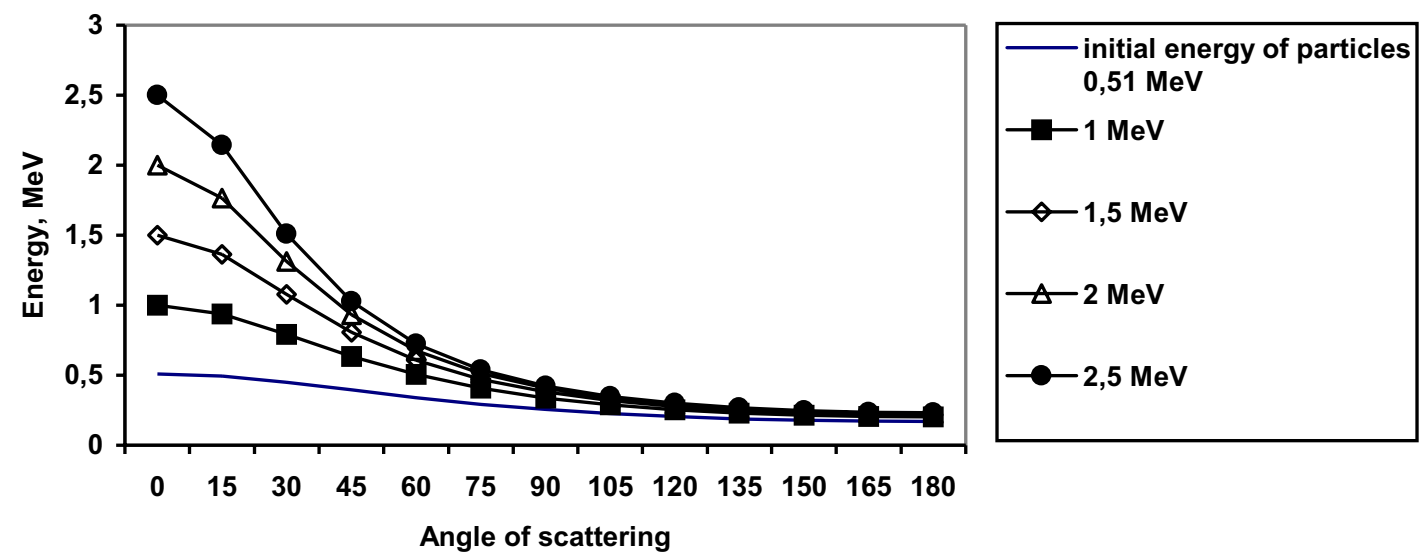

Fig 5. Connection between the energy of cosmic particles $(\mathrm{MeV})$ and the angle of the Compton's scattering

Table 1. Maximum energy of cosmic particles $(\mathrm{MeV})$ and scattered particles $(\mathrm{MeV})$ because of the Compton's effect in the crystal of a detector

\begin{tabular}{|l|c|c|c|c|c|}
\hline Maximum energy of the HCRF particles, MeV & $0,5-1$ & $1-1,5$ & $1,5-2$ & $2-2,5$ & More than 2,5 \\
\hline $\begin{array}{l}\text { Energy of the HCRF particles after the } \\
\text { Compton's scattering, MeV }\end{array}$ & $0,46-0,86$ & $0,86-1,3$ & $1,3-1,7$ & $1,7-2,2$ & 2,2 and more \\
\hline
\end{tabular}

show the back scattering $\left(\Theta=180^{\circ}\right)$ of quanta with a high energy $\left(h v_{0}>>0,51 \mathrm{MeV}\right)$ approximating to $0,25 \mathrm{MeV}$, and at an angle of $\Theta=90^{\circ}-$ to $0,51 \mathrm{MeV}$.

The calculation results of connection between gamma-quanta of a different energy and the angle of scattering is presented in Fig 5.

The energy values of initial particles and those of particles after the Compton's scattering in the detector of a gamma-spectrometer are illustrated in Table 1.

Hence, the energy of initial particles is summed up with that of particles after the Compton's scattering in the crystal of a detector and form a gamma-spectrum. The effect of muons in the gama-spectrum (Fig 3) practically consists of the Compton's scattering.

\section{Observation results}

During the last 25 years the monitoring of the HCRF was carried out in Vilnius. The obtained results were averaged by hours, days, months, years. The instability of the HCRF in the mentioned time intervals and changes in meteorological processes were investigated [4], including cardiovascular disease changes in Vilnius. Thus, variations in the integral spectrum of the HCRF were used as an indirect indicator of geomagnetic field variations influencing the above mentioned effects.

To make a detailed investigation of the HCRF course near the ground surface an integral range of 0,3$4 \mathrm{MeV}$ and more was divided into four parts: I - 0,31,2 MeV; II - 1,2-1,6 MeV; III - 1,6-4 MeV; IV - 4 $\mathrm{MeV}$ and more. Measurements were carried out in the mentioned ranges of energy. Such an example is pre-

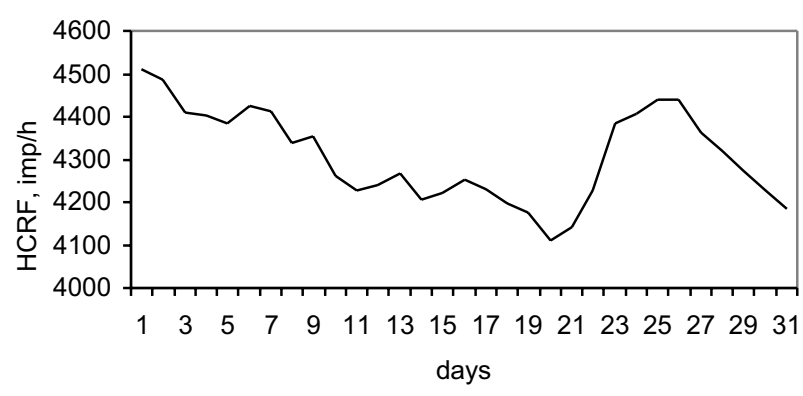

Fig 6. Course of averaged day integral values of the HCRF in July 2002 in Vilnius

sented in Figs 6, 7. Here a gradual decrease of the averaged day values of the HCRF in the integral range (Fig 6 ) and in the energy range of $0,3-1,2 \mathrm{MeV}$ (Fig 7a) was observed on 1-20 July 2002.

In the other spectral intervals the course of the HCRF is different (Figs $7 b, c, d$ ); here the minimum of the HCRF values was observed in other days. Coincidence of the HCRF course in the integral and the first spectral intervals is the most probable (Figs 6,7 a) because the majority of particles belong to these spectral intervals and in addition major part of cosmic particles of a high energy are formed after the Compton's scattering effect.

The next part of the investigation of cosmic radiation was carried out at different energy ranges and different thickness of the lead protection (Fig 8). Decrease of the intensive particle number was observed at an energy range of $0,3-1,2 \mathrm{MeV}$ and a small thickness $(3 \mathrm{~cm})$ of the lead protection. Decrease of the HCRF becomes 


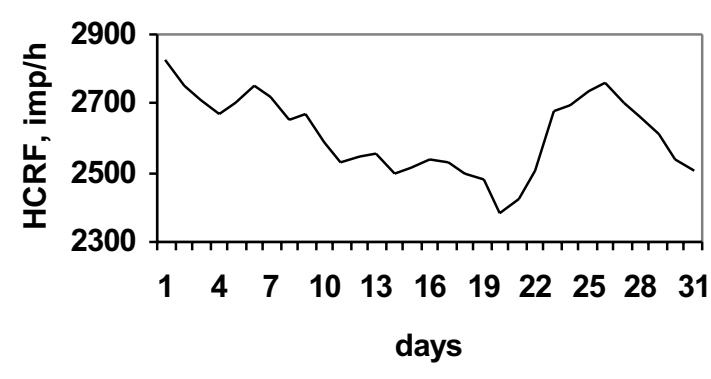

a

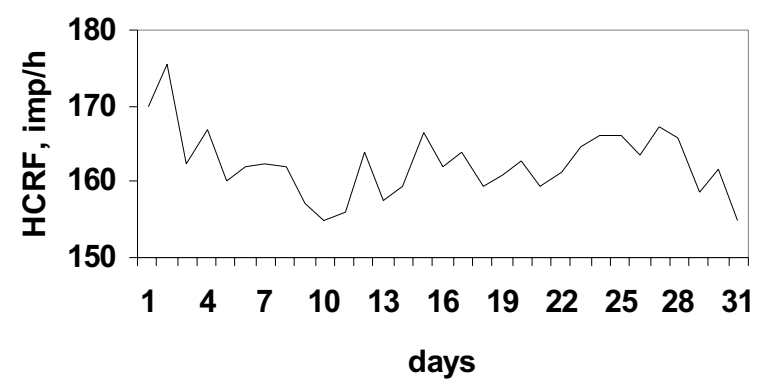

c
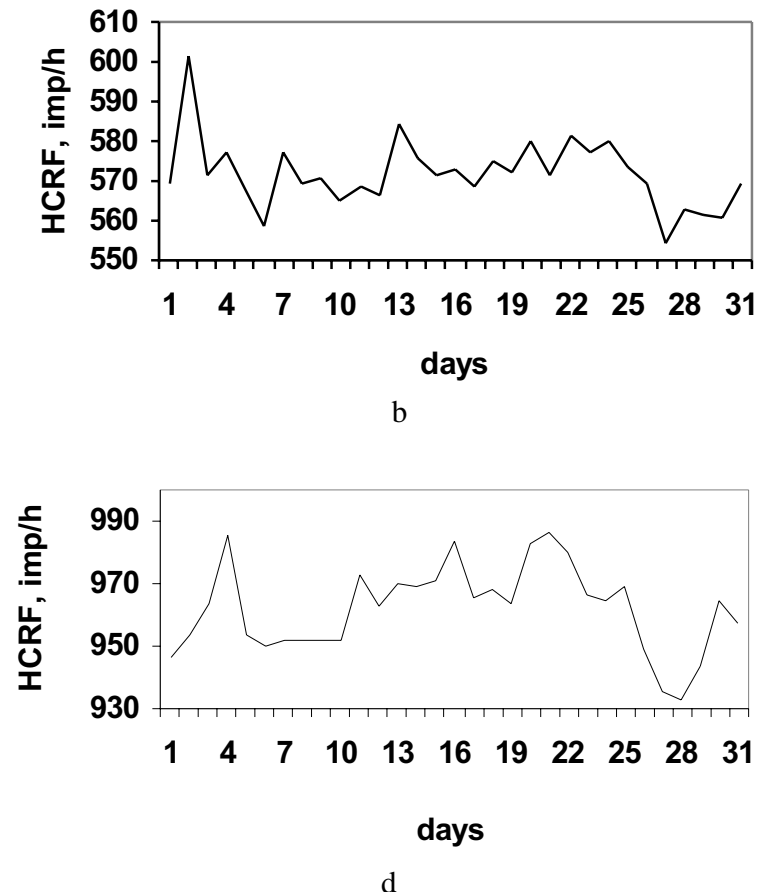

d

Fig 7. Course of averaged day values of the HCRF at different energy ranges: I $-0,3-1,2 \mathrm{MeV}$, II $-1,2-1,6 \mathrm{MeV}$, III $-1,6-$ $4 \mathrm{MeV}, \mathrm{IV}-4 \mathrm{MeV}$ and more in July 2002 in Vilnius

gradual at all the energy ranges increasing the lead protection.

Lead thickness of 9-12 cm practically does not absorb particles of a high energy ( $4 \mathrm{MeV}$ and more).

Under the lead protection of $9 \mathrm{~cm}$ decrease in the number of muons with energy of about $1,6 \mathrm{MeV}$ is stopped. This conclusion is real for the mentioned particles as far as $70 \%$ of the HCRF particles near the ground surface consist of muons [6]. It means that particles with an initial energy of $1,6 \mathrm{MeV}$ are absorbed by the lead protection of $9 \mathrm{~cm}$. Hence, to register the muons of 1,6 MeV energy under this lead thickness, the latter has to possess an initial energy of 3,2 MeV. Therefore, muons with this energy form the lower limit of hard cosmic radiation.

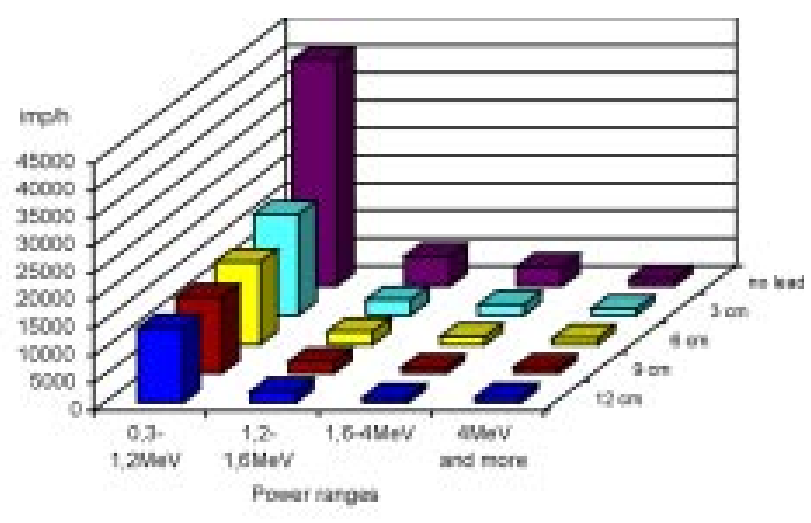

Fig 8. Change of impulse number per hour at different energy ranges after penetration of the HCRF through various thickness of lead protection
Another situation is observed for gamma-quanta as part of cosmic radiation. Moving through lead of $9 \mathrm{~cm}$ in thickness, gamma-quanta of $1,6 \mathrm{MeV}$ energy lose $70 \%$ of the initial energy. So to register a quantum of $1,6 \mathrm{MeV}$ energy under a lead protection, its initial energy has to be $2,7 \mathrm{MeV}$, i e less than that of muons $(3,2 \mathrm{MeV})$. As an after-effect, cosmic particles of a higher energy of 1,6 MeV under a lead protection of $9 \mathrm{~cm}$ form a spectrum as a straight line (Fig 3).

Graduation of the gamma-spectrometer by energy was carried out by the ${ }^{232} \mathrm{Th}$ radioactive source irradiating gamma-quanta as follows: $0,73,0,92,1,6,2,11$, $2,62 \mathrm{MeV}$. Three of the above presented initial energy quanta are fully absorbed by lead of $9 \mathrm{~cm}$ in thickness. Therefore, a gamma-spectrum can be formed by quanta of a maximum energy of $2,62 \mathrm{MeV}$.

The number of registered impulses after the passing of cosmic particles through different layers of lead during one hour is presented in Fig 9. Here decrease of the particle number of radionuclide ${ }^{232} \mathrm{Th}$ with a background and the background only increasing the protection is observed. The particle number of a radioactive source is approaching the background value (Fig 9).

The number of gamma-quanta of a high energy near the ground surface is decreased, that is why in the background formation of a gamma-spectrometer the main role is played by muons with energy of 3-4 MeV and more.

Analysing the tendency of the HCRF course at various energy ranges in Vilnius in 2001-2002, it is found out that the course of averaged HCRF day values from the previous to the next day in the majority of cases is 

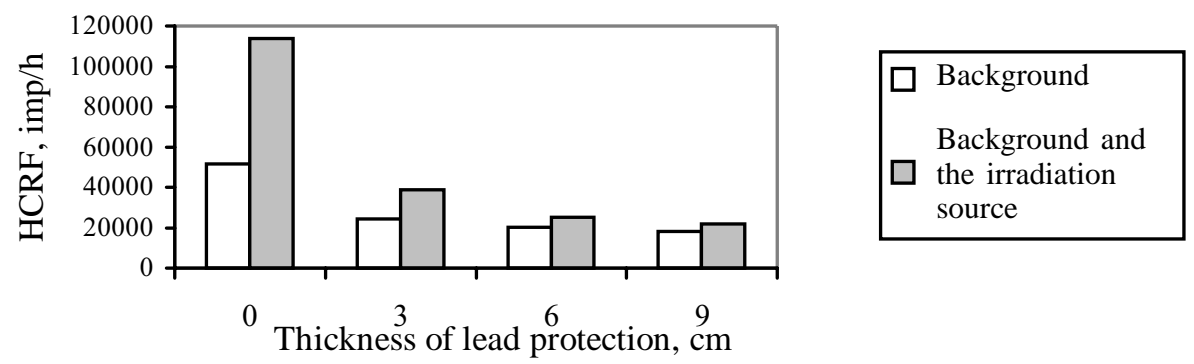

Fig 9. Change of impulse number per hour for the background and a ${ }^{232} \mathrm{Th}$ source of 2,62 $\mathrm{MeV}$ energy of gamma-quanta and the background of a gamma-spectrometer only after passing various thickness of lead protection

Table 2. Course of the HCRF at four energy ranges in Vilnius in 2001-2002.

\begin{tabular}{|c|l|c|c|c|c|}
\hline \multirow{2}{*}{$\mathrm{Nr}$} & \multicolumn{2}{|c|}{ Course of the HCRF } & \multicolumn{2}{|c|}{2001} & \multicolumn{2}{c|}{2002} \\
\cline { 3 - 6 } & & Absolute value & Per cent & Absolute value & Per cent \\
\hline 1 & Decrease at all the energy ranges & 24 & 6,5 & 31 & 9,5 \\
\hline 2 & Increase at all the energy ranges & 24 & 6,5 & 95 & 26,0 \\
\hline 3 & $\begin{array}{l}\text { Decrease at three and increase at } \\
\text { one energy range }\end{array}$ & 87 & 24,0 & 110 & 30,1 \\
\hline 4 & $\begin{array}{l}\text { Decrease at two and increase at two } \\
\text { energy ranges }\end{array}$ & 136 & 37,2 & 94 & 25,8 \\
\hline 5 & $\begin{array}{l}\text { Decrease at one and increase at } \\
\text { three energy ranges }\end{array}$ & 94 & 25,8 & 94 \\
\hline
\end{tabular}

different, including the impulse number and process direction.

The same simultaneous course of the HCRF at all the energy ranges was rarely observed in 2001-2002.

The everyday course of the HCRF at four energy ranges is presented in Table 2 .

The obtained results given in Table 2 confirm approximately the same results of a simultaneous decrease and increase of the HCRF at all the energy ranges in 2001 and 2002. It is probably connected with changeable action of the geomagnetic field on the flux of primary cosmic particles, that is why it increases or decreases the secondary HCRF near the ground surface. In practice it means that the altitude of atmospheric layers is also changed where muons are formed, and they reach the ground surface from different distances.

The most probable situation occurs in the case of a simultaneous increase and decrease at two energy ranges of the HCRF (Table 2). Thus the HCRF variations near the ground surface indirectly define the geomagnetic instability in the upper atmosphere which influences the human health.

\section{Conclusions}

1. A lead protection of the detector of a gammaspektrometer is improved. The protection consists of many lead plates which are placed at a certain distance among one another to stop the development of muon shower in the lead.

2. Limited energy of $1,6 \mathrm{MeV}$ needed for a muon to pass through the lead thickness of $9 \mathrm{~cm}$ is defined.
3. The course of the HCRF in $80-85 \%$ of cases is different at various energy ranges during a year.

4. It is found out that for registering gamma-quanta with 1,6 MeV energy of ${ }^{232} \mathrm{Th}$ under a lead protection of $9 \mathrm{~cm}$, initial energy of $2,7 \mathrm{MeV}$ is required.

5. The most probable course of the HCRF near the ground surface is simultaneous increase and decrease at two energy ranges.

6. Simultaneous decrease of the HCRF in all energy ranges makes $6,5-8,5 \%$ and increase $-6,5-9,6 \%$.

7. Variations of the HCRF near the ground surface indirectly characterize the effect of the geomagnetic field on the flux of primary cosmic rays and human organism.

\section{References}

1. Juozulynas, A.; Styra, D.; Syrusiene, V.; Kielaite, G. On the Possibility of Prognosis of a Leap in the Number of Heart and Vascular Diseases by Hard Cosmic Rays Flux Variations. Acta Medica Lituanica, Vol 7, No 4. Vilnius: Academy of Sciences of Lithuania, 2000, p 213-216.

2. Styro, D.; Gaspariūnas, J.; Usovaitè, A. Search of optimum method and energy range of hard cosmic radiation to predict a change of cardiovascular diseases. Westnik IAELPS (Вестник МАНЭБ), Vol 8, No 1, Sankt-Petersburg: IAELPS, 2003, p 89-94 (in Russian).

3. Styro, D. Regularities of hard cosmic rays flux variation near the ground surface. Environmental Engineering (Aplinkos inžinerija), Vol VI, No 2. Vilnius: Technika, 1996, p 9-11.

4. Styro, D.; Gaspariūnas, J.; Bogdanovič, A.; Syrusienè, V.; Usovaite, A. On prognostic correlation between a change 
of hard cosmic ray flux and cardiovascular diseases in Vilnius 1997-2001. Westnik IAELPS (Вестник МАНЭБ), Vol 8, No 6, Sankt-Petersburg: IAELPS, 2003, p 39-46 (in Russian).

5. Stoupel, E.; Abramson, J.; Domarkiene, M.; Shimskoni, M.; Sulkes, J. Space proton flux and the temporal distribution of cardiovascular deaths. International Journal of Biometeorology, Vol 40, No 2, 1997, p 113-116.

6. Grieder Peter, K. F. Cosmic rays at Earth. Elsevier, Amsterdam, 2001, 1093 p.

7. Rivin, Yu. R. Modulation of the galactic cosmic ray flux by cyclic variations of solar magnetic fields. International Journal of Geomagnetism and Aeronomy, Vol 1, No 3, 1999.

8. Ziegler, J. F. Terrestrial cosmic ray intensities. IBM Journal of Research and Development, Vol 42, No 1, 1998, p 117-139.

9. Gaisser, T. K.; Stanev, T. Cosmic rays. 1995. http:// pdg.lbl.gov.

10. Gorshkov, G. V. Gamma-radiation of radioactive elements and fundamentals of calculation of protection from radiation. Moscow-Leningrad, Academy of Sciences of USSR, 1989. 292 p (in Russian).

\section{KIETOSIOS KOSMINĖS SPINDULIUOTĖS VARIACIJU YPATUMAI PRIE ŽEMĖS PAVIRŠIAUS DĖL GEOMAGNETINIO AKTYVUMO SVYRAVIMU}

\section{Styra, J. Gaspariūnas, A. Usovaitė}

$\mathrm{S}$ a n trauk a

Analizuojamas pirminių kosminių dalelių virtimo antrine spinduliuote prie Žemès paviršiaus transformacijos mechanizmas. Iš publikacijų žinoma, kad antrinès kosminès spinduliuotès pagrindinę dali sudaro miuonai. Jie atsiranda dèl branduolinių reakcijų tarp pirminių kosminiu protonų ir atmosferos dujų branduolių. Didžiausios miuonų koncentracijos atmosferos sluoksnyje formuojasi apie $15 \mathrm{~km}$ aukštyje. Dèl trumpos miuonų egzistencijos trukmès $(2 \mu \mathrm{s})$ jų kiekis prie Žemès paviršiaus priklauso nuo šio sluoksnio aukščio svyravimų. Todèl prie Žemès paviršiaus registruojamas nepastovus miuonų srautas. Jo variacijos susiję su meteorologinių procesų kitimais, Saulès radiacijos nestabilumu, geomagnetinio lauko svyravimais ir t. t., o minètieji procesai turi poveiki žmogaus organizmui.

Prie Žemès paviršiaus atlikti tik kietosios kosminès spinduliuotès komponentès matavimai. Tam tikslui buvo patobulintas gama-spektrometro jutiklio apsauginis sluoksnis: padaryti tarpeliai tarp švininių plokštelių liūčių efektui švine sumažinti, veikiant kosminei radiacijai, ir mažų energijų dalelių itakai išvengti bei pagerinti matavimų rezultatų tikslumą.

Nustatyta, kad jutiklio $9 \mathrm{~cm}$ storio švininis apsauginis sluoksnis visiškai sugeria $1,6 \mathrm{MeV}$ energijos miuonus. Užregistruota, kad radionuklido ${ }^{232} \mathrm{Th} 1,6 \mathrm{MeV}$ energijos gama kvantai praranda $70 \%$ energijos tame pačiame apsauginiame sluoksnyje. 2001-2002 m. atlikta kietosios kosminès spinduliuotès srauto (KKSS) eigos prie Žemès paviršiaus analizè. Tirta keturi energiniai intervalai: I - 0,3-1,2 MeV, II - 1,2-1,6 MeV, III $1,6-4 \mathrm{MeV}, \mathrm{IV}-4 \mathrm{MeV}$ ir daugiau ir gauta skirtinga KKSS eiga. 2001-2002 m. vienu metu ji visuose intervaluose buvo nuo 6,5 iki 9,6\%. Gautieji rezultatai netiesiogiai rodo atmosferos sluoksnio aukščio, kuriame formuojasi didžiausios miuonų koncentracijos, pokyti laike. Šis pokytis priklauso nuo meteorologiniu ir geomagnetinio lauko pokyčių, ir tai turi įtakos žmonių sveikatai.

Raktažodžiai: kosminè spinduliuotè, miuonai, gama kvantai, energiniai intervalai, švininis apsauginis sluoksnis.

\section{ОСОБЕННОСТИ КОЛЕБАНИЯ ПОТОКОВ ЖЁСТКОГО КОСМИЧЕСКОГО ИЗЛУЧЕНИЯ У ЗЕМНОЙ ПОВЕРХНОСТИ ВСЛЕДСТВИЕ КОЛЕБАНИЙ ГЕОМАГНИТНОЙ АКТИВНОСТИ}

\section{Д. Стыро, Й. Гаспарюнас, А. Усовайте}

P е 3 ю м е

Анализируется механизм перехода первичных космических частиц во вторичное излучение у земной поверхности. Известно, что основную часть вторичного космического излучения у земной поверхности составляют мюоны. Они образуются в результате ядерных реакций между первичными протонами и ядрами атмосферных газов. Максимальное количество частиц мюонов образуется в атмосферном слое, расположенном на расстоянии 15 км от земной поверхности. Из-за сравнительно непродолжи-тельного времени жизни мюона $(2 \mu \kappa c)$ количество этих частиц у земной поверхности зависит от изменения высоты этого слоя.

Поэтому у земной поверхности регистрируются непостоянные потоки мюонов, колебания которых связаны с изменением метеорологических процессов, нестабильностью солнечной радиации, колебаниями геомагнитного поля и т. д., а упомянутые процессы воздействуют на человеческий организм.

У земной поверхности проводились измерения потока жёсткой составляющей космического излучения. С этой целью была усовершенствована защита детектора гаммаспектрометра: созданы небольшие расстояния между свинцовыми пластинками, чтобы уменьшить ливневые потоки в свинце, вызываемые космической радиацией и воздействием частиц малой энергии для повышения точности измерений.

Установлено, что свинцовая защита детектора толщиной 9 см полностью поглощает мюоны с энергией 1,6 МэВ, а гамма-кванты радионуклида ${ }^{232} \mathrm{Th}$ теряют $70 \%$ энергии при прохождении через ту же самую свинцовую защиту.

Проведен анализ хода потока жёсткого космического излучения (ПЖКИ) в четырёх энергетических интервалах: I - 0,3-1,2 МэB, II - 1,2-1,6 МэВ, III - 1,6-4 МэВ, IV 4,0 МэВ и более в 2001-2002 гг.

Обнаружен различный ход ПЖКИ в этих интервалах. Одновременное совпадение хода ПЖКИ во всех интервалах получено только в 6,5-9,6 \% случаев в 2001-2002 гг.

Полученные результаты косвенно отражают непостоянство высоты атмосферного слоя во времени, в котором образуется максимальная концентрация мюонов. Однако это непостоянство связано с изменением метеорологических процессов и колебаниями геомагнитного поля, что воздействует на состояние здоровья человека.

Ключевые слова: космическое излучение, мюоны, гамма-кванты, энергетические интервалы, свинцовая защита. 